\title{
University Libraries and Government Publications: A Survey
}

By GEORGE CALDWELL

$\mathrm{H}$ OW SHOULD A UNIVERSITY LIBRARY treat its government publications? Some argue for a separate collection. ${ }^{1}$ Others insist that documents should be placed in the library's general collection cataloged like other publications. ${ }^{2}$ A third group concludes either system will work and that there are no grounds for preferring one arrangement to another. ${ }^{3}$

At the University of Kansas Library, a survey was made of other university libraries' methods of handling documents. Probably the thing that surprised us most was the clear majority which contended that a separate collection of government publications produces a superior quality of bibliographical service. More division of opinion had been expected, in view of the past controversy on the matter. (Jur question was worded as follows: "Do you feel that a separate collection of government publications, in comparison with a collection in which they are integrated into the regular collection, tends to result in: (a) Higher quality of bibliographical service by the library, (b) Inferior quality of bibliographical service by the library, (c) No great difference in quality of bibliographical service, (d) Don't know." The pros and cons were voted as follows: higher 15; lower, 1. Four indicated that there was no great difference, and three, that

1 Mahala Saville, "Government Publications-What Shall We Do with Them?" Library Journal, LXV (1940), 681-84.

Andrew D. Osborn, Serial Publications; Their Place and Treatment in Libraries (Chicago: ALA, 1955 ), pp. $27-28,186$.

3 Mary Brown Humphrey, "Obstacles and Opportunities in Specialized Treatment of Federal Depository Documents," CRL, XII (1951), 45; Violet Abbott Cabeen and C. Donald Cook, "Organization of Serials and Documents," Library Trends. II (1953), 202.
Mr. Caldwell is Documents Librarian, University of Kansas.

they did not know. Thus, 65 per cent of the respondents indicated that a separate collection produced a higher quality of bibliographical service, whereas only 4 per cent thought it produced a lower quality.

In practice, a separate documents collection usually means many documents are not cataloged, for economic and other reasons. Therefore, the following question was asked (the number of responses to each part of the question is given in parentheses):

If government publications are in a separate collection and are not entered in the main public catalog, do you feel this is:

(3) A positive advantage.

(15) Has disadvantages, but these are compensated for by the advantages of a separate collection.

(2) Not a serious omission.

(3) Serious omission for undergraduates.

(5) Serious omission for graduate students, faculty, and researchers.

(5) Serious omission for library staff.

The raw numbers above can be somewhat misleading, since several librarians checked more than one statement. In terms of the actual number of librarians, 18 checked one of the first three statements, while only five checked the last three. Thus on this question more than three-fourths of the respondents tended 
to favor the separate collection, compared with less than one-fourth who had serious misgivings.

The librarians were asked how satisfied they were with their own system for handling government publications and whether they wished for any changes. In reply, most of the librarians appeared satisfied with what they had, although many qualified their satisfaction by noting improvements which could be made or by explaining that their existing situation limited the changes which could be made. The fact that people can be satisfied with various systems, of course, does not mean that one system is superior to another.

\section{Nature of The Survey}

What kind of survey was this? On what sort of sample was it based?

The survey developed as part of a general reappraisal of the organization of government publications at the University of Kansas, which in turn was based on the problem of future building plans. Other library surveys on the documents problem had been made with helpful results, notably those by Eastin ${ }^{4}$ and Jackson. But they did not deal with some of the questions in which we were especially interested.

Questionnaires were sent to $31 \mathrm{mem}$ bers of the Association of Research Libraries in April 1958, addressing them to the Documents Librarian at each school. Twenty-three libraries ( 75 per cent) returned the questionnaire. ${ }^{6}$

Admittedly, the sample is small. This does not necessarily mean, however, that

\footnotetext{
4 R. B. Eastin "Let's Use Public Documents!" Library Journal, LXXIII (1948), 1554-58.

"Isabel H. Jackson. "Advantages and Disadvantages of a Subject System of Classification as Key to a Depository Collection," CRL, XII (1951), 42-45.

- The libraries in our sample were from the following universities: California, Chicago, Cincinnati, Colorado. universities: Indiana, Iowa, Iowa State, Joint University Libraries, Kentucky. Louisiana State. Minnesota, MisLibraries, Kenth Carolina, Ohio State, Rutgers, Stanford. Texas, UCLA, Virginia, Washington, Washington of St. Louis, and Wisconsin. (We also queried Oklahoma State. since they have one of the strong documents collections in this area, but their reply is not tabulated in these returns).
}

it is insignificant. The membership roster of the ARL represents a group of prominent libraries which were especially interested in organizing materials for research. Since we were concerned with libraries problems similar to those at Kansas, we omitted in general the very largest and the most specialized libraries. Within these limitations, however, we tried to include most of the libraries on the list, to balance the sample. This gave us a group of thirty-one libraries, twentythree of which returned our questionnaire. Most of the libraries in our sample have collections of 750,000 to $1,000,000$ volumes, with a handful of both larger and smaller ones. Most of them also serve from one thousand to three thousand graduate students, with a few either larger or smaller.

It may be objected that the sample is biased because most of the questionnaires were answered by documents or reference librarians, who may tend to have a particular point of view about documents, resulting from the nature of their work. This objection is valid up to a point, and their opinions should obviously be supplemented by those of other groups affected by documents. However, the opinions of documents librarians also deserve a certain special weight, since as specialists, they are the staff members most likely to have first-hand familiarity with the actual problems encountered in trying to do research in government publications. Moreover, the survey opinions were confirmed to a considerable degree by other investigations conducted on the Kansas campus. Faculty members in the departments which use documents most heavily and regularly-Political Science, History, and Economics - tended to favor a separate collection.

The questionnaires indicated that eight libraries had completely separate collections of government publications, four had predominantly separate collections, six handled most governments publications like any other publications, 
and five libraries had quite mixed systems. Hence about three-fourths of these libraries give some sort of separate or special treatment to documents, and only about one-fourth treat documents completely like other publications. These figures correspond roughly to those in the Eastin and Jackson surveys, which indicates that our sample is probably representative. Our figures also hint strongly that in spite of the oft-expressed desire to treat government publications like any other publications and the desire for single catalogs and unified collections, there are likely strong practical reasons which cause so many of these research libraries to give their documents special treatment.

In trying to evaluate the factors for and against each type of documents organization, it seems especially pertinent to consider the views of two libraries that had had experience with both main types of documents organization. In both cases, the librarians answering the questionnaire volunteered that after experience with documents under both controls, they preferred the separate collection. These conclusions are confirmed by oth$\operatorname{ers}^{7}$ who have known both main types of documents organization and among faculty on the Kansas campus.

\section{Non-Federal Documents and Separate Collections}

The arguments in the literature for separate collections apply most strongly to federal documents, where a mass of complicated and unwieldy material can be handled efficiently by a system of printed catalogs and classification. But for all the other types of government publications-especially state, local and foreign-we had doubts about whether separate uncataloged collections were as necessary or worked as well. This prob-

7 William F. Barr, "Advantages and Disadvantages of the Superintendent of Documents Classification as a Key to a Depository Collection," CRL, XII (1951), 42; Edmon Low, "Governulent Documents at Oklahoma A. \& M.,"'Serial Slants, VII (1956), 17. lem has not been discussed in any detail in the literature, where most attention has centered primarily on federal and United Nations documents. So in the second half of our questionnaire, we asked about the handling of separate collections for non-federal documents. This part of our questionnaire was answered by almost all the librarians who had separate or partially separate collections-16 of the 17. The opinion ran as follows:

Favor state and local documents in separate collection: Yes, 12. No, 4.

Favor foreign documents in separate collection: Yes, 12. No, 4.

Favor United Nations documents in separate collection: Yes, 15 . No, 1.

Thus, the librarians with separate collections for federal documents tended strongly to that other types of documents should also be separate from the library's general collection. Further, most of them stated the non-federal documents should not only be separate from the general collection, but also together with the federal documents.

\section{Arrangement of Non-Federal Documents}

The next problem on our minds was how to arrange the non-federal documents if we established a separate collection. Although the numbering system for U. S. and U. N. publications could be definite, this was not so for foreign, state and local documents. So we asked the librarians presidling over separate collections how they proceeded.

The most common single pattern in these separate collections was to arrange non-federal documents alphabetically by area, agency, and title. However, the approach varied according to how distinct the documents collection was and which type of document was being shelved.

Over half of the libraries used an alphabetical arrangement, either in whole or in part, for state documents. Only two 
libraries were using the Swank system for state documents, although two others were switching to it. With foreign documents, the picture was fairly evenly divided between alphabetical vs. LC or Dewey. With UN documents, the leading arrangement was the UN classification scheme. There were not enough specific references to local documents to make it clear how many of the libraries actually had significant collections of them.

How satisfied were the librarians separate collections with their systems for non-federal documents? Because of the variety of organization used and the size of our sample, our data were too scattered and limited for precise conclusions. About the only group large enough to show anything were the eight libraries which were using or had used the alphabetical area-agency-title arrangement. Five libraries had found it satisfactory, but three had not. One librarian considered this arrangement as too confusing and time-consuming for shelving, one was converting to the Swank schedules, and another was converting the documents of its own state to the LC system.

\section{Cataloging of Non-Federal Documents}

We also wanted to know how these separate collections managed the cataloging of non-federal documents. So we inquired, "Are your non-federal documents given full cataloging (subject, title, author) in either a special card catalog or in the library's main card catalog? Is your system satisfactory?"

The great bulk of the separate collections responding to this particular question, 8 out of 12 , said they did not fully catalog non-federal documents. Of these, two were satisfied. Another was dissatisfied, and one said, quite significantly, that if they had more staff and funds, a card catalog of state and foreign documents would be useful because of the uneven coverage in printed indexes.

Another thing that bothered us about separate uncataloged collections of gov- ernment publications was a mental image of students and faculty having to wade through dozens of different catalogs to cover the field and find what they wanted. So we asked the librarians of separate collections about this, as follows: "If you do not fully catalog your nonfederal documents, do your patrons have to learn to use several printed catalogsMonthly Catalog of U. S. Government Publications, Monthly Checklist of State Publications, U. N. Documents Index, etc.-in order to gain access to the publications? Is this satisfactory?"

To our surprise, this seemed hardly a serious problem at all in the experience of these librarians; 12 of them thought this arrangement worked out satisfactorily, only one equivocated with a "not entirely." The consensus was that many of their patrons were faculty, research personnel, and graduate students, who learned quickly from instruction.

\section{Conclusion}

After studying the available literature, conducting this survey, visiting other libraries, canvassing local faculty and student opinion, and discussing the problem among ourselves, we have decided to work toward a separate centralized collection of government publications at the University of Kansas Library, when building additions permit. Our plan is to arrange most new U. S. government publications in the documents section by the Superintendent of Documents classification. Most U. S. documents in the main library already classified by Dewey will probably be moved into the documents section and kept under Dewey until time permits the documents staff to convert them to the Superintendent of Documents classification. However, because of a strong divisional branch library system, most scientific documents will probably continue to go to the science libraries and be cataloged in the main catalog and the science libraries' catalogs. Our collection of printed UN documents will 
remain in the documents section, uncataloged for the most part, arranged by UN documents symbols and sales numbers. Because of the incomplete coverage in printed indexes, our library catalogers will continue to catalog and classify Kansas and foreign government publications, but most of these will probably be housed in the documents section. We hope, by taking the foregoing steps, to make the complex mass of government publications easier for faculty and students to get at, especially on the graduate and serious research level where these difficult materials are needed in quantity. We also believe this move will enable the library to service and control documents more efficiently and economically.

\section{Tauber to Australia on Project}

Dr. Maurice F. Tauber, Melvil Dewey professor of library service at Columbia University and editor of $C R L$, will spend March through August in Australia on a Fulbright assignment to assist in a study of the resources of the research libraries of the country. His address will be the Commonwealth National Library, Canberra, Australia. On his way to Australia during February he will visit libraries in Tokyo, Hong Kong, and Singapore. He will return in September by way of Europe. During his absence please address any inquiries regarding articles or other matters relating to $C R L$ to his office at Columbia University and they will be directed to the individuals who will carry on the editing of the magazine while he is away.

\section{Manuals for Reference Departments \\ (Continued from page 20)}

\author{
Checking in \\ Aids: \\ List of Foreign Publishing Terms \\ List of the Months in French, Ger- \\ man, Italian, Portugese and Span- \\ ish \\ Roman Numerals \\ Listing Missing Periodicals \\ Preparing Periodicals for Binding \\ Preparing Periodicals for Cardboard \\ Covers \\ Making New Periodical Subscription \\ Records \\ Receiving Bound Periodicals from Cata- \\ loging \\ Circulating Periodicals \\ Reference Techniques \\ Records: \\ Attendance Record \\ Loan Records: \\ To Faculty and Staff \\ To other Departments in the Library \\ To other Colleges and Universities \\ (Interlibrary Loan) \\ To the Bindery
}

To Carrells and Studies

Recalling Periodicals or Books Loaned to the University Staff

J. Special Procedures

Mississippi Agricultural Experiment Station and Mississippi Agricultural Extension Service Card Catalog

Bibliography of State Experiment Station Publications

K. Miscellaneous

Elevator

Booklift

Telephone

Supplies

L. INTERLIBRARY LOANS

General Interlibrary Loan Code, 1952

M. Special Divisions

Government Documents

Vertical Files

Mississippi and Rare Books Room including the Cage

Manuscript Collection

ApPendix A. "Guide to the Facilities of Mitchell MEMORIAL LibraRy."

INDEX 